\title{
Some aquatic insects and invertebrates as bioindicators for the evaluation of bacteriological pollution in El-Zomor and El-Mariotya canals, Giza, Egypt
}

\author{
Fatma K. Adham ${ }^{1}$; Refaat M. Gabre ${ }^{1}$ and Ibrahim A. Ibrahim ${ }^{2}$ \\ 1- Department of Entomology, Faculty of Science, Cairo University \\ 2- Department of Zoology \& Entomology, Faculty of Science, Helwan \\ University
}

\section{ABSTRACT}

Some aquatic insects and invertebrates were used for monitoring the effect of bacteriological pollution upon water quality during two years (October, 2001- August, 2003) at six sampling sites situated at El-Zomor and El-Mariotya canals (branches from the River Nile), Giza Governorate, Egypt. Results obtained revealed that 5 species of bacteria (Escherichia coli, Klebsiella pneumonia, Enterococcus faecalis, Streptococcus faecium \& Proteus mirabilis) were detected from water samples. K. pneumonia, S. faecium and $P$. mirabilis were not detected at IIIZ site and; $S$. faecium was not detected at IIZ sampling site. Meanwhile only two species (E. coli \& E. faecalis) were detected in all El-Mariotya canal sampling sites. E. coli \& E. faecalis showed high bacterial counts during summer months. The bacterial species isolated from aquatic insects belong to different orders mainly Diptera; Ephemeroptera and Odonata; however, there is no isolation of bacteria from aquatic invertebrate belonging to orders Cladocera \& Cyclopoida. The 5 bacterial species that were detected in the water samples were isolated from the collected aquatic insects at IZ sampling site, while at IIZ sampling site 4 species (E. coli, K. pneumonia, E. faecalis \& P. mirabilis) and only two species (E. coli \& E. faecalis) at IIIZ sampling site. However, only 2 species of bacteria (E. coli \& E. faecalis) were isolated from ElMariotya canal. It is clear that some aquatic stages of Diptera, Ephemeroptera and Odonata could be selected as bioindicator of water bacterial pollution.

Key words: Freshwater - Bioindicators - Bacteria - Pollution

\section{INTRODUCTION}

Contamination of water supplies by pathogenic organisms as bacteria, viruses and other parasitic organisms is an important factor in the spread of many diseases. The tests for water safety in use today are aimed at detecting particular indicator organisms or a bioindicator, living within natural communities to monitor the impact of disturbance communities. Bioindicator can also be used in urban settings and in agricultural communities.

Biomonitoring has been around since the beginning of the twentieth century by using macro-invertebrates to assess water quality and degrees of pollution in rivers subject to sewage contamination (Islam et al., 1994; Anesio et al., Barlough el al., 1998) as water contaminated by inflows from sewage systems is also relatively high in bacterial counts.

At the beginning of this century Lemly and King (2000) reported on an insectbacteria bioindicator for assessing detrimental nutrient enrichment in wetlands. Hunter et al., (2002) determined faecal bacteria in the waters of an upland area and also studied the influence of agricultural land use in Derbyshire, England. Mahilum et al. (2003) detected Wolbachia infections in Culex pipiens complex mosquitoes from 
the upper Rhine Valley in Germany and Cebu City in Philippines. Ramaiah et al. (2004) studied abundance of pollution indicator and quantified various groups of pathogenic bacteria in Mumbai waters, Maharashtra, India. Zamxaka et al., (2004) during his study on the microbiological quality of drinking waters from different water sources in the Eastern province in South Africa, identified 54 different species of microorganisms. Accordingly the aim of the present study was the use of some aquatic insects and invertebrates as bioindicators for the evaluation of bacteriological pollution in El-Zomor and Mariotya canals (branches from the Nile River) during two year from October 2001-Augest 2003.

\section{MATERIAL AND METHODS}

\section{DESCRIPTION OF STUDIED AREA:}

The studied area lies between $30^{\circ} 00^{\prime}$ and $31^{\circ} 15^{\prime}$ latitudes and $31^{\circ} 00^{\prime}$ and $31^{\circ} 15^{\prime}$ longitudes and is situated in the Western region of Cairo, Giza Governorate, Egypt. El-Zomor and El-Mariotya canals (branches from the River Nile) are irrigation canals, penetrating a vast cultivated area of the Western side of the River Nile and with many inhabited sites scattered around them.

The length of El-Zomor canal is about $27 \mathrm{~km}$ and a width ranging between 10 and $25 \mathrm{~m}$. It runs from Tirsa at the Southern part of the studied area toward the North ending in El-Ryyah El-Nasseri. The bottom depths of El-Zomor canal at Cairo University, Al-Mi'timddyah and Bashtil are 2.00, 1.70 and $1.60 \mathrm{~m}$, respectively.

El-Mariotya canal contributes a drain with a length about $30 \mathrm{~km}$ and a width of more than $25 \mathrm{~m}$ and extends from Giza Governorate at the Southern part of the studied area ending in El-Ryyah El-Nasseri. They penetrate a vast cultivated area of western side of the River Nile. The bottom depths of El-Mariotya canal at Kirdasah, Nahya and Kafr Hakim are 2.50, 2.00 and $1.75 \mathrm{~m}$ respectively.

These two canals are parallel to each other and represented the base location of the water sample sites chosen during the present study. On each canal, three sites were chosen, the distance between each site is $2 \mathrm{Km}$ (Figure 1).

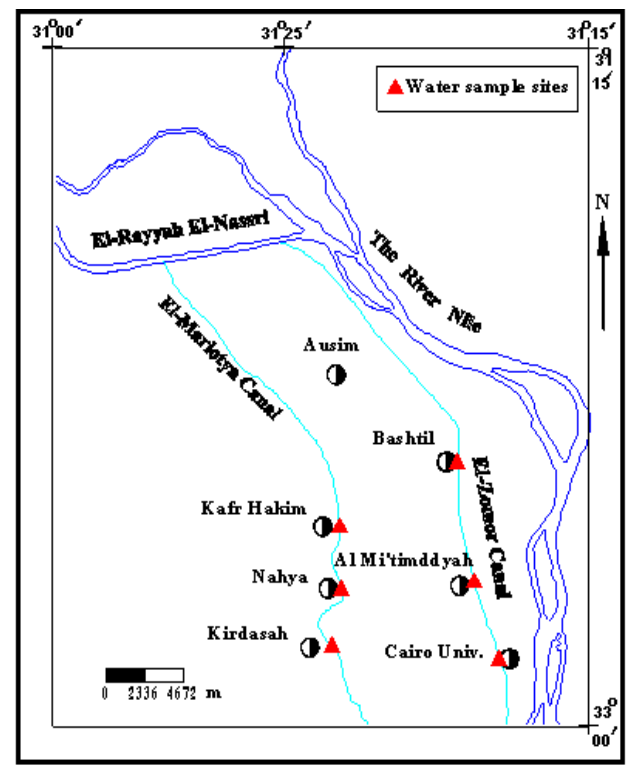

Figure (1): Location of the studied water sampling sites at El-Zomor and El-Mariotya canals, Giza Governorate. 
Each site was visited once every two months from October, 2001 till August, 2003 for collecting water samples. The studied sites are located as follow:

\section{El-Zomor $(Z)$ canal:}

The first sampling site (IZ) was located under Tharwat bridge behind Cairo University about $14 \mathrm{Km}$ from the main branch of the River Nile. This area is occupied by many buildings, shops and restaurants with high human activities. Sanitary conditions were poor, presence of pipes regularly pouring their contents into the water streams, garbage and rubbish resulting from shops and restaurants were dropped in the river water all the year round. Invertebrate breeding water is considered as more or less quiet, turbid semi-shaded water. The second sampling site (IIZ) was chosen at AlMi'timddyah in the front of Bolak El-Dakror area. This site is characterized by its sandy land, many buildings and the presence of sewage pipes regularly pouring their contents in the running, turbid semi-shaded breeding water. Rodents are present in this area, moving everywhere. The third sampling site (IIIZ) was located nearby Bashtil village where buildings are scattered nearby cultivated areas. The sewage pipes as well as agricultural runoff were pouring their contents into the clear, sunny running water.

\section{El-Mariotya (M) canal:}

The first sampling site (IM) was chosen in the front of Kirdasa village, about 16 $\mathrm{Km}$ from the main branch of the River Nile, a well recognized village of high commercial activities dealing with carpet and textile manufacturing. Although the breeding water was running, it was turbid. The second sampling site (IIM) was located at the entrance of Nahya village. The buildings were scattered, the population communities deal with agricultural activities. The breeding water was running and clear. The third sampling site (IIIM) was situated nearby Kafr Hakim about $2 \mathrm{Km}$ from site IIM, where the agricultural activities as well as the buildings density were less as compared to site IIM. The breeding water was running and clear.

The computer program Surfer 7, 02 (2000) was used for the designation of the location map and its related collecting sites of water samples of the study area.

\section{Bacterial isolation from water:}

Collection of water samples for bacterial isolation was performed bimonthly during the summer and winter seasons for two years (October 2001-August 2003). The procedures and precautions regarding collection and transportation of aquatic invertebrates and insects from El-Zomor and El-Mariotya canals were carried according to the method suggested by WHO (1985). Faecal Coliforms (FC) and $E$. coli were enumerated by membrane filtration techniques at the laboratory of microbiology, Department of Entomology, Faculty of Science, Cairo University. Counts represent the total number of bacteria as colony-forming units (CFU) per 100 $\mathrm{ml}$ (WHO, 1985).

\section{Bacterial isolation from insect:}

Collection of immature stages of aquatic invertebrate for bacterial isolation was performed bimonthly, during the period of investigation (October, 2001-August, 2003). The collected aquatic immature insects were decontaminated externally. They were washed for 10 minutes in a solution of $0.1 \% \mathrm{NaOCl}$, then for 5 minutes in $5 \%$ formalin and then followed by four changes of sterile water. An aliquot of the final wash water was inoculated into nutrient broth and incubated for 24 hours to assure that no viable bacteria could be removed from the surface of the aquatic invertebrates. Aquatic invertebrates (10 from each), were ground in $1 \mathrm{ml}$ of nutrient broth in an electrical homogenizer, housed in air-laminar flow under complete aseptic conditions. For isolation and identification of the internal bacteria, $0.1 \mathrm{ml}$ of the broth was plated 
on the surface of blood agar and MacConkey agar. Plates were incubated at $37^{\circ} \mathrm{C}$ in an incubator for 24 hours under aerobic conditions. The isolated bacteria were identified to genus level by colony morphology, texture and Gram staining. Biochemical reactions were performed according to El-Mishad (1978), Delaat (1984) and Collines et al. (1989). Identification of the isolated bacteria to species level was achieved by using the standardized identification system, the API20E (according to the instruction of the manufacture).

\section{RESULTS}

Bacteriological analysis of the insect and invertebrate breeding water sites at El-Zomor (IZ, IIZ \& IIIZ) and El-Mariotya (IM, IIM, \& IIIM) canals, reveals the existence of 5 bacterial types; Escherichia coli, Klebsiella pneumonia, Enterococcus faecalis, Streptococcus faecium and Proteus mirabilis.

Results obtained are illustrated in Fig. (2) showing the mean of bacterial counts of E. coli, K. pneumonia, E. faecalis, S. faecium and P. mirabilis isolated from breeding water samples collected bimonthly from El-Zomor sites and El-Mariotya ones. Data obtained show that the bimonthly distribution of isolated E. coli and $E$. faecalis are detected in all breeding sites at El-Zomor and El-Mariotya canals. Moreover they also show a certain periodicity in their distribution through their detection. Meanwhile $K$. pneumonia and P. mirabilis are detected at IZ and IIZ, S. faecium is detected only at IZ site.

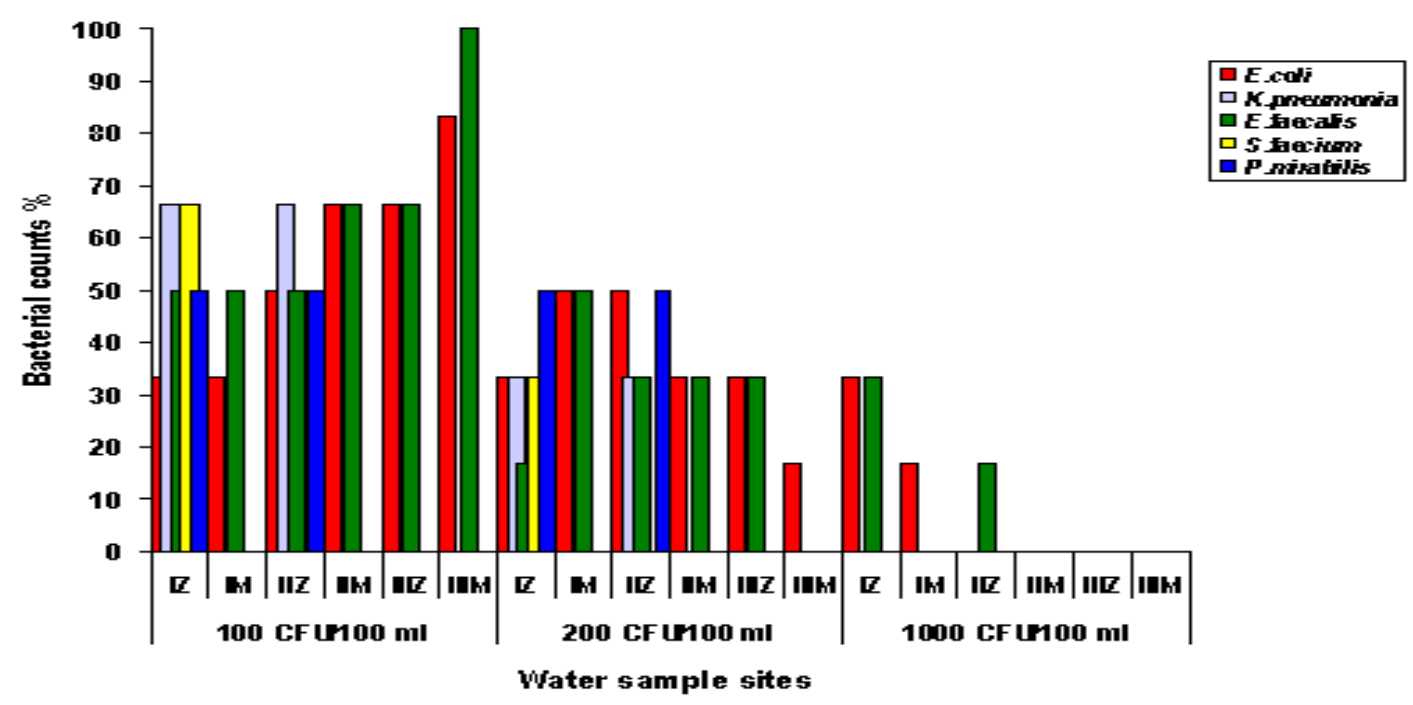

Figure (2): Percentage of bacterial counts in breeding water sample at El-Zomor and El-Mariotya canal sites.

The average bacterial counts isolated from aquatic invertebrates, including insects collected from El-Zomor sites (IZ, IIZ \& IIIZ) and El-Mariotya (IM, IIM \& IIIM) ones are presented in Table (1).

Results also reveal that: E. coli is not isolated from the Chironomidae, Ephydridae, Caenidae, Baetidae and from the aquatic invertebrate belonging to Cladocera (Daphnia) and Cyclopoida (Cyclops) in both canal sites. Similar results are also obtained in case of K. pneumonia, E. faecalis, S. faecium and P. mirabilis. 
Table (1): Average bacterial counts isolated from aquatic insects collected from El-Zomor and ElMariotya canals during October, 2001- August, 2003.

\begin{tabular}{|c|c|c|c|c|c|}
\hline Insect families & $\begin{array}{c}\text { E. coli } \\
\text { Mean } \pm \mathrm{SE}\end{array}$ & $\begin{array}{c}\text { K. pneumonia } \\
\text { Mean } \pm \text { SE }\end{array}$ & $\begin{array}{l}\text { E. faecalis } \\
\text { Mean } \pm \text { SE }\end{array}$ & $\begin{array}{l}\text { S. faecium } \\
\text { Mean } \pm \text { SE }\end{array}$ & $\begin{array}{l}\text { P. mirabilis } \\
\text { Mean } \pm \mathrm{SE}\end{array}$ \\
\hline Syrphidae & $\begin{array}{ll}\text { IZ: } & 10.33 \pm 0.56\left(10^{3}\right) \\
\text { IIZ: } & 8.67 \pm 1.20\left(10^{2}\right) \\
\text { IM: } & 7.78 \pm 0.33\left(10^{2}\right)\end{array}$ & $\begin{array}{l}\text { IZ: } 2.50 \pm 0.56\left(10^{2}\right) \\
\text { IIZ: } 5.17 \pm 0.52\left(10^{1}\right)\end{array}$ & $\begin{array}{ll}\text { IZ: } & 7.33 \pm 0.33\left(10^{3}\right) \\
\text { IIZ: } & 8.00 \pm 0.37\left(10^{2}\right) \\
\text { IM: } & 6.44 \pm 0.80\left(10^{2}\right)\end{array}$ & $\begin{aligned} \text { IZ: } 3.83 & \pm 1.49\left(10^{2}\right) \\
- & - \\
& -\end{aligned}$ & $\begin{array}{c}\text { IZ: } 3.00 \pm 0.37\left(10^{2}\right) \\
\text { IIZ: } \\
7.33 \pm 0.33\left(10^{1}\right) \\
- \\
-\end{array}$ \\
\hline Ceratopogonidae & $\begin{array}{ll}\text { IZ: } & 6.83 \pm 0.31\left(10^{3}\right) \\
\text { IIZ: } & 7.00 \pm 0.37\left(10^{2}\right) \\
\text { IIIZ: } & 5.67 \pm 0.49\left(10^{2}\right) \\
\text { IM: } & 6.89 \pm 0.80\left(10^{2}\right) \\
\text { IIM: } & 4.00 \pm 0.49\left(10^{2}\right) \\
\text { IIIM: } & 8.90 \pm 0.33\left(10^{1}\right)\end{array}$ & $\begin{aligned} \text { IZ: } & 1.83 \\
\text { IIZ: } & \pm 0.81\left(10^{2}\right) \\
& \\
& - \\
& - \\
& - \\
& -\end{aligned}$ & $\begin{array}{ll}\text { IZ: } & 4.00 \pm 0.52\left(10^{3}\right) \\
\text { IIZ: } & 6.83 \pm 0.31\left(10^{2}\right) \\
\text { IIIZ: } & 3.83 \pm 0.31\left(10^{2}\right) \\
\text { IM: } & 5.17 \pm 0.56\left(10^{2}\right) \\
\text { IIM: } & 3.33 \pm 0.42\left(10^{2}\right) \\
\text { IIIM: } & 7.79 \pm 0.33\left(10^{1}\right)\end{array}$ & IZ: $\begin{aligned} 2.67 & \pm 0.42\left(10^{2}\right) \\
& - \\
& - \\
& - \\
& - \\
& -\end{aligned}$ & 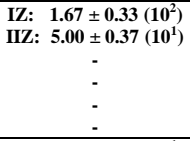 \\
\hline Culicidae & $\begin{array}{ll}\text { IIZ: } & 3.83 \pm 1.49\left(10^{2}\right) \\
\text { IIIZ: } & 2.67 \pm 0.42\left(10^{2}\right) \\
\text { IIM: } & 2.00 \pm 0.24\left(10^{2}\right) \\
\text { IIIM: } & 5.89 \pm 0.27\left(10^{1}\right)\end{array}$ & IIZ: $\begin{aligned} 2.50 & \pm 0.56\left(10^{1}\right) \\
& - \\
& - \\
& -\end{aligned}$ & $\begin{array}{l}\text { IIZ: } 4.33 \pm 0.52\left(10^{2}\right) \\
\text { IIIZ: } 1.78 \pm 0.22\left(10^{2}\right) \\
\text { IIM: } 1.78 \pm 0.22\left(10^{2}\right) \\
\text { IIIM: } 4.89 \pm 0.22\left(10^{1}\right)\end{array}$ & $\begin{array}{l}- \\
- \\
- \\
- \\
-\end{array}$ & IIZ: $\begin{aligned} & 2.67 \pm 0.42\left(10^{1}\right) \\
&- \\
&-- \\
&\end{aligned}$ \\
\hline Tabanidae & $\begin{array}{l}\text { IIIZ: } 2.56 \pm 0.21\left(10^{2}\right) \\
\text { IIM: } 2.56 \pm 1.00\left(10^{1}\right) \\
\text { IIIM: } 7.56 \pm 0.22\left(10^{1}\right)\end{array}$ & $\begin{array}{l}- \\
- \\
- \\
\end{array}$ & $\begin{array}{l}\text { IIIZ: } 1.11 \pm 0.22\left(10^{2}\right) \\
\text { IIM: } 2.11 \pm 0.63\left(10^{2}\right) \\
\text { IIIM: } 6.44 \pm 0.80\left(10^{1}\right)\end{array}$ & $\begin{array}{l}- \\
- \\
\end{array}$ & $\begin{array}{l}- \\
- \\
\end{array}$ \\
\hline Coenagrionidae & $\begin{array}{ll}\text { IZ: } & 5.33 \pm 0.21\left(10^{3}\right) \\
\text { IIZ: } & 2.67 \pm 0.42\left(10^{2}\right) \\
\text { IIIZ: } & 1.00 \pm 0.64\left(10^{2}\right) \\
\text { IM: } & 5.89 \pm 0.56\left(10^{2}\right) \\
\text { IIM: } & 1.00 \pm 0.64\left(10^{2}\right) \\
\text { IIIM: } & 3.45 \pm 0.40\left(10^{1}\right)\end{array}$ & 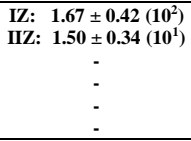 & $\begin{array}{ll}\text { IZ: } & 3.33 \pm 0.56\left(10^{3}\right) \\
\text { IIZ: } & 1.67 \pm 0.33\left(10^{2}\right) \\
\text { IIIZ: } & 0.87 \pm 0.02\left(10^{2}\right) \\
\text { IM: } & 4.67 \pm 0.49\left(10^{2}\right) \\
\text { IIM: } & 0.83 \pm 0.02\left(10^{2}\right) \\
\text { IIIM: } & 2.67 \pm 0.34\left(10^{1}\right)\end{array}$ & IZ: $\begin{aligned} & 2.60 \pm 0.56\left(10^{2}\right) \\
&- \\
&- \\
&- \\
&- \\
&\end{aligned}$ & $\begin{array}{l}\text { IZ: } 1.33 \pm 0.49\left(10^{2}\right) \\
\text { IIZ: } 1.50 \pm 0.34\left(10^{1}\right) \\
\\
- \\
\\
\\
- \\
- \\
\end{array}$ \\
\hline Aeshnidae & $\begin{array}{ll}\text { IZ: } & 3.83 \pm 0.31\left(10^{3}\right) \\
\text { IIZ: } & 1.67 \pm 0.33\left(10^{3}\right) \\
\text { IIIZ: } & 0.90 \pm 0.04\left(10^{3}\right) \\
\text { IM: } & 3.65 \pm 0.21\left(10^{3}\right) \\
\text { IIM: } & 0.70 \pm 0.08\left(10^{3}\right) \\
\text { IIIM: } & 2.00 \pm 0.24\left(10^{3}\right)\end{array}$ & 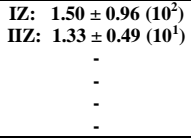 & $\begin{array}{ll}\text { IZ: } & 2.67 \pm 0.42\left(10^{3}\right) \\
\text { IIZ: } & 1.50 \pm 0.34\left(10^{2}\right) \\
\text { IIIZ: } & 0.68 \pm 0.03\left(10^{2}\right) \\
\text { IM: } & 3.33 \pm 0.42\left(10^{2}\right) \\
\text { IIM: } & 0.64 \pm 0.08\left(10^{2}\right) \\
\text { IIIM: } & 1.33 \pm 0.49\left(10^{1}\right)\end{array}$ & IZ: $\begin{aligned} 1.00 & \pm 0.52\left(10^{2}\right) \\
& - \\
& - \\
& - \\
& - \\
& -\end{aligned}$ & 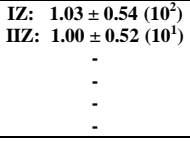 \\
\hline
\end{tabular}

IZ, IIZ \& IIIZ = El-Zomor canal sites.

IM, IIM \& IIIM = El-Mariotya canal sites.

\section{DISCUSSION}

Our results revealed that 5 species of bacteria (E. coli, K. pneumonia, E. faecalis, S. faecium \& P. mirabilis) were detected in the breeding water sites at El-Zomor canal. E. coli and E faecalis were detected at IZ, IIZ \& IIIZ. K. pneumonia, S. faecium and $P$. mirabilis were not detected at IIIZ sampling site and; $S$. faecium was also not detected at IIZ sampling site.

Only two species E. coli \& E. faecalis were detected in all El-Mariotya canal sampling sites. Meanwhile, $K$. pneumonia, S. faecium and P. mirabilis were not detected.

The 5 bacterial species that were detected in the water samples were isolated also from the collected aquatic insects belonging to different orders mainly: Diptera, Ephemeroptera and Odonata; however no isolation of bacteria from aquatic invertebrate belonging to Cladocera (Daphnia) and Cyclopoida (Cyclops).

Results obtained show that the bacterial counts isolated from El-Zomor and El-Mariotya canals revealed that IZ sampling site is more contaminated with E. coli, E. faecalis and $S$. faecium although these bacteria are present at the two other sampling sites (IIZ, IIIZ) but in low counts, this might be attributed to the high sewage discharge, human activities, the movement of water which is more or less stagnant, and high electrical conductivity which is often used as an indirect index of pollution (Best and Ross, 1977).

Results also showed high bacterial counts during summer months during this period. This might be attributed to the great human activities (many buildings, shops, restaurants, sewage pipes and agricultural runoff). The highest peak of bacterial counts were detected during June and August 2002 and 2003 (above 1000 CFU / 100 $\mathrm{ml} \&$ above $200 \mathrm{CFU} / 100 \mathrm{ml}$ ). The lowest counts (above $100 \mathrm{CFU} / 100 \mathrm{ml}$.) are found during remnant months as illustrated in Fig. (2). Similar results were obtained by Hunter and McDonald (1991), Geldreich (1996), Tian et al. (2002) and Hyland et $a l$, (2003), they stated that the faecal indicator bacteria populations normally peak in the spring and summer months if the source of faecal pollution is livestock or 
agricultural runoff. This suggests that a constant source of contamination, such as human waste, was responsible for the majority of this contamination (Brezonik and Stadelmann, 2002).

According to the results obtained the aquatic stages of Diptera, Ephemeroptera and Odonata could be selected as a reliable bioindicator of water bacterial pollution for assessing nutrient impacts on macroinvertebrate communities (Lemly and King, 2000). Similarly, Leal et al, (2003) concluded that Campsurus notatus (Ephemeroptera: Polimitarcidae) is an important bioindicator in Lake Batata, increasing the turnover rate of Nitrogen $(\mathrm{NH} 4+)$ at the sediment-water interface and bacterial production in cores incubated with natural sediment. It is also clear that bauxite tailings reduce the nutrients turnover rates in impacted regions of lake and influence bacterial production.

\section{REFERNCES}

Anesio, A.M.; Abreu, P.C. and Esteves, F.A. (1997). Influence of the hydrological cycle on the bacterioplankton of an impacted clear water Amazonian lake. Microbiol. Ecol., 34: 66 - 73.

Barlough, J.E.; Reubel, G.H. Madigan, J.E.; Vrederoe, L.K.; Miller, P.E. and Rikihisa, Y.(1998). Detection of Ehrlichia risticii, the agent of Potomac horse fever, in freshwater stream snails (Pleuroceridae: Juga spp.) from Northern California. Appl. Environ. Microbiol., 64: 2888 - 2893.

Best, G.A. and Ross, S.L. (1977). River pollution studies. Liverpool University press. Liverpool, London, $92 \mathrm{p}$.

Brezonick, P.L. and Stadelmann, T.H. (2002). Analysis and predictive models of storm water runoff volumes, loads and pollutant concentrations from watersheds in the Twin cities metropolitan area, Minnesota, U.S.A. Water Res., 36: $1743-1757$.

Collins, C.H.; Lyne, P.M. and Grange, J.M. (1989). Microbiological methods. Butter worth and company, London.

Delaat, A.N.C. (1984). Microbiological for the allied health professions. Lea and Febiger, U.S.A.

El-Mishad, A. M.(1978).Manual of practical microbiol.Vol.,1. Al-Ahram press, Cairo.

Geldreich, E.E.(1996). Pathogenic agents in freshwater resources. Hydrol. Proc.10: 315-333.

Gorman, M.J. and Paskewitz, S.M. (2000). Persistence of infection in mosquitoes injected with bacteria, J. Invert. Pathol., 75 (4): 296 - 297.

Hunter, B.R.; Colvord, J.M.; Lechevallier, M.W.; Binder, S. and Berger, P.S. (2002). Water borne diseases. Emerg. Infect. Dis., 75: 544 - 545.

Hunter, C. and Mac Donald, A. (1991). Seasonal changes in the sanitary bacterial quality of water draining a small upland catchments in the Yorkshire Dales. Wat. Res., 25: 447 - 453.

Hyland, R.; Byrne, J.; Selinger, B.; Graham, T.; Thomas, J.; Townshend, I. and Gannon, V. (2003). Spatial and temporal distribution of faecal indicator bacteria within the oldman river basin of South Alberta, Canada. Water Qual. Res. J. Canada, 38 (1): 15-32.

Islam, M.S.; Drasar, B.S. and Sack, R. B. (1994). The aquatic flora and fauna as reservoir of Vibrio cholerae: a review. J. Diarrh. Dis. Res., 12: 87 - 96. 
Kaspar, C.W.; Burgess, J.L.; Knight, I.T. and Colwell, R.R. (1990). Antibiotic resistance indexing of Escherichia coli to identify sources of faecal contamination in water. Canad. J. Microbiol., 36: 891 - 894.

Leal, J.J.F.; Esteves, F.A., Farjalla, V.F. and Enrich-Prast, A. (2003). Effect of Campsurus notatus on $\mathrm{NH}_{4}{ }^{+}$, DOC fluxes, $\mathrm{O}_{2}$ uptake and bacterioplankton production in experimental microcosms with sediment-water interface of an Amazonian lake impacted by bauxite tailings, Internat. Rev. Hydrobiol., 88: $167-178$.

Lemly, A.D. and King, R.S. (2000). An insect - bacteria bioindicator for assessing detrimental nutrient enrichment in Wetlands, Wetlands, 20: 91 - 100.

Luxananil, P.; Atomi, H.; Panyim, S. and Imanaka, T. (2001). Isolation of bacterial strains colonizable in mosquito larval guts as noval host cells for mosquito control, J. Biosci. \& Bioengin., 92 (4): 342 - 345.

Mahilum, M.M.; Storch, V. and Becker, N. (2003). Molecular and electron microscopic identification of Wolbachia in Culex pipiens complex populations from the Upper Rhine valley, Germany and Cebu city, Philippines. J. Am. Mosq. Cont. Assoc., 19 (3): 206 - 210.

Ramaiah, N.; Vrushali, K. and Sadhasivan, A. (2004) Abundance of pollution indicator and pathogenic bacteria in Mumbai waters. Current Sci., 87 (4): 435- 439.

Tian, YQ.; Gong, P.; RadkeJ, D. and Scarborough, J. (2002). Spatial and temporal modeling of microbial contaminants on grazing farmlands. J. Environ. Qual. 31: 860-869.

World Health Organization (1985). Guidelines for drinking water quality. Vol.I, Recommendations. Geneva, Switzerland. 130 p.

Zamxaka, M.; Pironcheva, G. and Nyo, M. (2004). Bacterial community patterns of domestic water sources in the Gogogo and Nkonkobe area of the Eastern Cape Province, South Africa. Water S.A., 30 (3): 341 - 346.

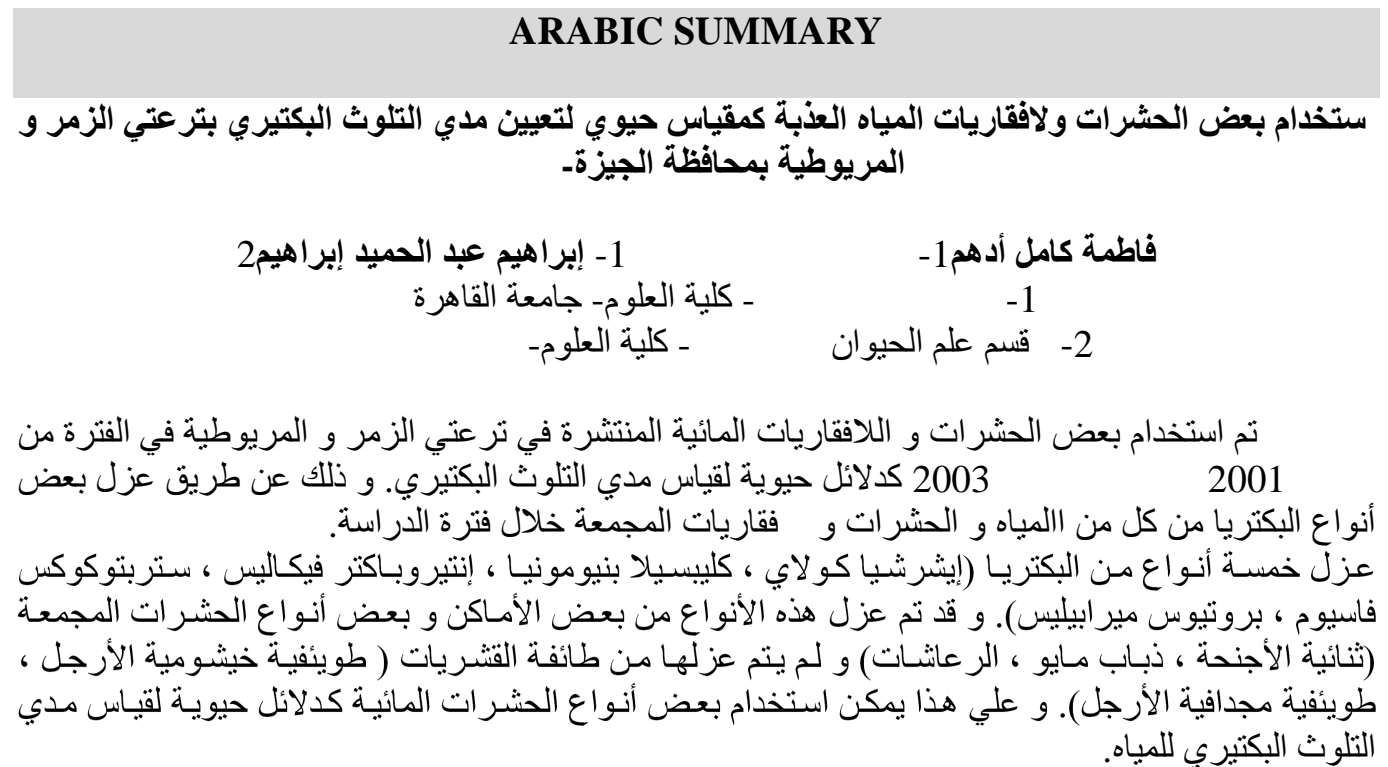

